\title{
Theory of Imagery in Studies of the Change Process
}

\author{
Denize Grzybovski* \\ E-mail address: gdenize@upf.br \\ Faculdade de Ciências Econômicas, Administrativas e Contábeis (FEAC) - Universidade de Passo Fundo (UPF) \\ Passo Fundo, RS, Brazil \\ Cristhiane Oliveira da Graça Amâncio \\ E-mail address: camancio@cpap.embrapa.br \\ Centro de Pesquisa Agropecuária do Pantanal - Empresa Brasileira de Pesquisa Agropecuária (Embrapa Pantanal) \\ Corumbá, MS, Brazil
}

\section{Elcemir Paço-Cunha}

E-mail address: paco.cunha@ufjf.edu.br

Departamento de Ciências Administrativas - UFJF

Centro de Pós-Graduação e Pesquisas em Administração - UFMG

\begin{abstract}
This article aims to demonstrate the analytical power of the imagery concept for an organizational analysis. The gaps in organizational studies justify building new reference pictures in the organizational culture, with imagery as a starting point, considering subjectivity as an object of the phenomenology investigation and imagery as an object of anthropology and sociology. The analytical perspective follows the sociology of the knowledge and, in this context, applications of anthropology, general sociology, analytical and social psychologies are presented. The result is an organizational imagery accessed by the objectivity of the subjects, through the language, where the images attributed to the reality emerge.
\end{abstract}

Key words: imagery; organizational studies; organizational change.

Received 13 July 2006; received in revised form 09 April 2007.

Copyright (C) 2007 Brazilian Administration Review. All rights reserved, including rights for translation. Parts of this work may be quoted without prior knowledge on the condition that the source is identified.

* Corresponding author: Denize Grzybovski

Rua Uruguai, 1391, Apto. 402, Passo Fundo, RS, 99010-111, Brazil.

Tel.: +55 543316 8245; +55 5499222777. 


\section{INTRODUCTION}

Establishing relations between the imagery and the process of organizational change is intriguing and challenging because of its complexity, and also because of the attempt that involves different theoretical trends in a single construction and for the unprecedented feature in the organizational field. In 1979, Larçon and Reitter attempted this proximity, using organizational imagery to demonstrate the influence of imagery on the company's identity, approaching what organizational theory calls organizational culture. Aktouf (1993), in turn, deeply criticizes the organizational researchers for improperly confiscating the terms of other sciences, among which the concept of culture stands out. After analyzing the classic works of anthropology, the original context of the term culture, the author makes a reference to the accusation of the abusive importation, made by Gladys Symons, of the notions and analytical systems of ethnology by the organizational theories.

In this article, the intention is to return to the term imagery in the organizational context, in an attempt to provide theoretical support in order to identify the specific imagery built by the members of an organization around the change process. There are gaps in organizational studies that justify the attempt of building new reference pictures of the culture in organizational studies, recuperating the origin of its concept in anthropology. It is assumed that the imagery presents significant analytical potential in organizational studies, if we consider subjectivity as an object of investigation of the phenomenology, and the imagery as an object of investigation of anthropology and sociology. Subjectivity is "the capacity of receiving the sense, doing something with it and producing sense, giving sense, turning it into a new sense every time” (Castoriadis, 1999, p. 35). It is in phenomenology, anthropology, and sociology that imagery and change try to establish a relation among themselves and are supported, having the company as a place of appropriation and sharing (Aktouf, 1993).

The mental process and the references concerning the unconscious, according to the need for an explanation of the text content, is considered in Castoriadis's perspective (1999), for whom the subject is socially defined but has the possibility of being something different from his social definition as well, without ever becoming totally distanced from it, owing to the subjectivity that it involves. The base of the subjectivity is in the psyche, like magma, and it becomes impossible to decompose its totality in sets in order to submit it to conjectural logic.

The reason why this study is being carried out is an attempt to offer theoretical support to organizations that are trying to build and sustain an organizational imagery to consolidate or implement changes which satisfy the interests of the homogenous groups. It does not mean that spontaneous adhesion will be pursued, since there is no homogeneity in a specific imagery of an organization. However, it is relevant to know the predominant imagery and its interface with change, highlighting the intersubjective aspects of organizational every-day life.

One of the analytical perspectives adopted here is the sociology of knowledge, for its focus on everything which involves knowledge. This offers elements to comprehend the process by which a specific reality is solidified in the subject, develops, transmits, and maintains itself in social interactions in the organizational context (Berger \& Luckmann, 2002).

Thus, in the context of this theoretical essay, applications of anthropology and sociology for the investigation and comprehension of the phenomenon of change are presented through the collective imagery according to the way it manifests in organizations, which can represent obstructing or facilitating elements of change. It is not the intention of this essay to advance in methodological proposals for the empirical investigation of the theme since the content of the case histories may vary according to the perception of each researcher's reality, particularities of the interviewers' personal history and the context where they build their imagery. This unconscious imagery that structures the actions of each subject group in organizations is deduced, inferring from what is given, aiming to 
preserve the inner subjective reality and allowing the researcher to construct his own idea of the scenario. Reality is "a quality belonging to the phenomena that we recognize as having an independent being from our own volition (we cannot wish they do not exist)", and in this paper, it will be used in the conception and with the limitations presented by Berger and Luckmann (2002, p. 11).

The content is divided into three parts. Each one is the object of a specific presentation. The first is dedicated to discussing the process by which social realities are built and institutionalized. The second aims to conceptualize the imagery from the epistemological trends constructed by Gilbert Durand and Cornelius Castoriadis and their canons as an attempt at transposing elements from social imagery to the construction of organizational imagery, albeit without going deeper into the discussion of psychoanalysis. Finally, the third part of this paper presents the final considerations.

\section{THE SOCIAL CONSTRUCTION OF THE IMAGERY}

Imagery is socially constructed and goes naturally through the institutionalization processes (Berger \& Luckmann, 2002), involving the subjectivity in the language for the construction of socially shared objective realities. Once the organization is formed by people, the reality, whilst it is given, is also modified in the dynamics of everyday life. Thus, organizations have the capacity to create their own reality and, through their history, held in specific social-cultural contexts, incorporate aspects from it while remaining different from this context. Despite the dynamism, the given reality almost always represents the interests of the hegemonic groups.

In Trindade and Laplantine's point of view (1997), the reality consists of the fact that people, social objects and nature exist independently from the presence and meanings that people attribute to them. This existence itself forces reality to be something to be noticed and interpreted, directly connected to the social and natural environment, to the context.

In its construction, reality uses the real (human interpretation to reality through ideas, signs and symbols) and ideas (mental representations of the concrete and abstract things). This way, the reality can be analyzed by different social theories that involve the knowledge of anthropology, sociology, and psychoanalysis.

Anthropology and psychoanalysis, according to Lapierre (1995), are the subjectivity sciences based in the interpretive paradigm. By the specific objective of this study, the theoretical line follows the optic of anthropology and sociology, under the phenomenological paradigm. It is important to know the organizational dynamics from the collective imagery in a certain organization, not at the individual level.

For this reason, Lapierre (1995) argues that the approach sustained by Vico's conception is that, while contesting the dominant position of common sense in the traditional western philosophy, the ghost is emplaced as being able to conduct human thought to the truth and makes the world comprehensible. The ghost universe, formed by languages, history, literature and fables, is the base for human interpretation of the world (Lapierre, 1995).

Vico's interpretation of reality, reported by Lapierre (1995), is one of the forms of discussing the imagery. In the texts about imagery, independently of distinctions among trends, its relation with what is real is inevitable. The real appears as raw material for the imagery, because the imaginative capacity is presented in it (Lapierre, 1995; Trindade \& Laplantine, 1997) and, in a Marxist perspective, the human thought where the imaginative capacity is developed based in the human activity and in the social relations produced by this activity (Berger \& Luckmann, 2002).

Nietzsche (1844-1900), as cited in Berger and Luckmann (2002), however, added new perspectives concerning human thought as an instrument in the fight for survival and for power (the false 
conscience) which allows us to oppose the sociological view with the enterprising view of imagery and change. The power of an executive when instituting a change can be connected to his capacity of interpreting the imagery presented in the group he leads, be it in a conscious way or not, which brings all the inevitable relativity of his history to the organization according to Diltney (as cited in Berger \& Luckmann, 2002). The exercise of his authority, however, will be characterized by the aggressiveness originated from the fear of going too far with his authority and by the possibility of becoming a victim of the inner conflicts involving his success (Lapierre, 1995).

Analyzing this problem in the perspective of society, Castoriadis (1986) observes that man only exists through society and that each society is different from the others; it is a particular and singular form. Nevertheless, adds the author, society, as an assembly or meeting of subjects related to each other, and those related to things, are only kept united by institutions. Castoriadis (1986) understands institutions as a set of rules, language, instruments, procedures and methods that a given society builds to deal with things and subjects. The way these institutions are understood by subjects can change the predicted results (projected) by common sense.

Alluding to Hobbes, Lapierre (1995) opportunely recalls that imagination is responsible for perception, ideas, and the experience of reality that is capable of connecting images to wishes, speeding creative thought and action. Therefore, in an organizational perspective, it can be assumed that the imagery connects the intention to the human action and to all its consequences. In the organizational place, it is a social rational action that goes beyond the Weberian conception (Barreto, 1993), as it is oriented by values and ideologies (Serva, 1997).

Trindade and Laplantine (1997), who observe the modern societies characterized by the duality between subjectivity and objectivity, also observe the dualism presented here. The production of images connected to the affection needs the ideas conceived by intelligence to belong to the real, in the same way that the imagery intoxication that celebrates needs the sobriety of the science that works. In their words,

So, everything which is connected to the imagery would belong to the category of the fantasy, of the caprice, of the dispersion, of the evasion (to run away from the world), of the confusion, but also of the pleasure (to give and receive it), while the rationality conquered in the fight against our faculties (understood as forgering) of the intuition and sight, would be worried about obtaining the reality, that is, adhering to the world (Trindade \& Laplantine, 1997, p. 72).

Therefore, reality dispenses the imagination, for the researcher or for the manager, because it is possible to force something that did not exist before to exist or establish relations between two realities that were understood as distinct. Aware of the importance of imagery in the reality construction, the administrators can facilitate the implantation of the organizational change processes.

\section{SOCIAL IMAGERY AND ORGANIZATIONAL IMAGERY}

Throughout time, the term imagery has been studied under the most distinct perspectives, which resulted in different meanings and connotations according to the cultural and geographical contextualization. Altman (1995) presents the concept of imagination as an unfinished history that begins with the history of mankind. She points to the year 1709 as the initial mark for her conceptual analysis when Giambattista Vico (as cited in Altman, 1995) published the first work which contests the dominant position of common sense in the philosophical tradition of the West. The NorthAmerican epistemological conception, for instance, has a strong psychoanalytical orientation, which differs from the French connotation due to the meaning of the English language.

The North Americans make a great deal of effort to set connections among the aspects of the unconscious mind, present in the leader's personality (anguish, wishes, needs, character, personal style 
and ghosts subjacent to the exercise of the leadership) and psychological defenses that can inhibit the leader's action. This North-American focus stimulated Lapierre (1995) to invite a group of researchers, in 1984, to extend this approach and, so, in a collective effort, based on empirical data, to comprehend the influence of the unconscious strengths in the management and work of $\operatorname{organizations}^{(1)}$.

In another perspective, Enriquez, in 1974, used the term social imagery to understand the phenomenon of depression and repression in the organizations. Larçon and Reitter (1979) use the term organizational imagery meaning ghosts shared by a group of executives and by the staff of an organization. And, in 1984, Lapierre used the term imagery, in the psychoanalytical perspective, to describe the subjective way of the play directors at the moment of conceiving the shows to be performed (Lapierre, 1995).

To sum up, Enriquez and Larçon, just like Reitter, use imagery in the perspective of analytical psychology, alluding to the ghostly aspect of imagery, but adding a collective content to it, while Lapierre uses the term imagery in the individual connotation.

In the perspective of the social sciences, Baczko (1985) analyzes imagery concerning the relations of power and domination in the context of institutional relations (politics, education, work), bringing to the academic scenario the need to discuss not only the concept, but also the imbricate relations. The author questions the validity of studies into imagery, as academia should not only be worried about the clarification of how it is formed, but should also discuss the "multiple and complex functions which are involved in the imagery of collective life and, especially, in the exercise of power" (Baczko, 1985, p. 297).

The author also expresses some concern over the methodological rigor in the analyses of imagery and the inference of the scientists who, according to him, already have a natural tendency to disclose and demystify their object of study. Nevertheless, social imagery is observed neither in the structures that organize the dominant science nor in the forms of its specific way of working; the social actors who form the object of study should be observed in their absolute naked state. The scientists build a symbolic universe around the object, which characterizes some inference from the imagery not only from the object of study but also from that one built by the researcher. Baczko (1985) concentrates his incursion into imagery under the perspective of power relations, justifying the need for studying the manipulation of social imageries. In this light, exercising the symbolic power is not only adding the dimension of the illusionary to a certain reality as if it were another variant of analyses. For the author, alluding to Bourdieu's ideas (2001), the exercise of symbolic power doubles the effective domination because it appropriates the symbols and signs of the subjects through the construction of a system of representations that translates and legitimates order, which guarantees subservience of those who are dominated. Thus, imagery, besides being a place for the expression of desires and dreams is also a place of fights, conflicts, and suffering, in a situation involving the dominated ones and the strengths of oppression (Baczko, 1985).

The registration of social imageries are a strong contribution to the construction of identity by a society, distributing roles and social positions, building common sense around the codes of good behavior and installing myths and behavior models. Understanding this function of social imagery in society permitsthe analysis of the power legitimacy problem, since power is not analyzed through universal principles. Society needs to imagine and build its legitimacy reference. The legitimacy of power constitutes the object of conflicts and fights between the dominators and those who are dominated.

As for organizations, Baczko (1985) affirms that they are part of a symbolic universe that involves their way of working. This way, the production of the symbolic goods is limited. "The imagery becomes intelligible and communicable through the production of the speeches in which and by which the reunion of the collective representations in a language are effectuated" (Baczko, 1985, p. 311). In the symbolic universe, the function of the symbol is not only to institute a classification, but also to introduce values, to mold behavior and indicate the possibilities of success in its achievements. These 
symbolic systems, in which imagery acts, are socially constructed by the experience of the social actors involved in such reality. The unification of social imageries is permitted through the fusion between the truth and the included rules in the symbolic systems. Thanks to its complexity and its symbolic dimension, social imagery acts at a number of levels of collective life, performing multiple functions related to the subjects.

\section{Perspectives of ANAlysis Of the ORGANizATIONAl IMAGERY}

In the psychoanalytic perspective, Lacan $(1983,1985)$ develops a concept of imagery based on the thesis that the unconscious is structured with and by language. In the Lacanian optic there are three dimensions of thought registration (symbolic, real, imaginary) that work in the thought structure in an interlinked way, where the symbolic registration has the function of attributing meanings, but without closed signs. A single image can have many symbolic attributions in different cultural contexts. Real registration is responsible for piercing the subject speech, because the situations do not always occur in accordance with a person's view of the world. However, the registration of the imagery is directly linked to the apprehension of the signs, where they have the function of connecting a concept to an image aiming to capture a meaning.

The relations of imagery can be identified by speech (as opposed to Lacan's linguistic analysis), since the unconscious mind is structured as and by language. By this analysis, speeches are closed elements due to their load of signs. In the organizational context, it can be assumed that every organization has a symptom (characteristic, label), which comes from the unconscious mind. In private organizations this symptom can be attributed to the owner's imagery; in others, this symptom comes from the boss, which allows a predominance that Lancan calls master's speech ${ }^{(2)}$. This has been a great contribution for varied sources of analysis of the imagery effects in social relations.

Castoriadis (2000) uses the term imagery to question the human and social sciences with their rational conceptions that structure society as a consequence of man's materialistic and historical development, reducing the social relations to the level of relations depending upon historical determinism, but never for some action of the unconscious mind or the symbols directly linked to social imagery. For him, imagery is the main institution of the cohesion of society and where power struggles take place, which makes the idea of adequate and neutral symbolism inexistent. Society constitutes the symbolic order in references that already exist and this choice is not free.

For Castoriadis (2000), symbolism's domination of the institutions has the same language's domination dimension, except that it is remitted to something that is not symbolic. Speech is not independent of symbolism but it is taken by it. Therefore, it is concluded that when a society conceives an institution, it is done with all the networks of symbolic and rational relations. For this author, the symbolic relations are the relations between the imaginary function and its domination by the real function.

Lacan's definition that symbolism is neither symbolic nor real-rational, provides the functionality of each institutional system with its specific orientation that determines the choice and connections of the symbolic networks in its historical, cultural, social and economic context of each society. This way, forms of living and making their existence are stereotyped, distinguishing the important from the unimportant, increasing the existence of objects of practical achievement, affective and intellectual, individual or collective. This element is society imagery (Castoriadis, 2000). Constructing these stereotypes in organizations consists of executing the domination of the individual imageries and, consequently, guiding the real attitudes of the subjects for the processes of change according to the interests of the leadership, providing that these networks of symbolic relations, will be accepted as valid by most of the members. 
The discussions about imagery can be summarized into two trends, one of them supported by Durand $(1994,2002)$ and the other by Castoriadis $(1986,1996,2000)$. These two trends can be complementary when transposed to the organizational field.

In L'Imaginaire, Durand (1994) strongly criticizes the five centuries of rationalism which added factual empiricism as an obstacle to imagery. "The 'fact', together with the rational argument, appears as another obstacle to imagery, increasingly confused with delirium, the ghost of the dream, the irrational”. The abandonment of the image, in Durand's words (1994), is explained:

The method 'to discover the truth of the sciences' [...], by Descartes - invades all the fields of investigation of the true knowledge'. The image [...] is abandoned to the art of persuading the preachers, the poets and the painters; it will never have access to the dignity of an art of demonstration (p. 3).

Durand (1994, 2002) presents a dense work to retake a historical conceptualization of image, of imagination and of imagery from the critics and complements Sartre's work $(1964,1996)$. In the intellectual theories that Durand (2002) analyzed, he calls attention to the mistake in the concept of image, strictly empiricist to separate from pure logic thought, and the one from the formulas and notions used, accepting the letter as a form of expression without image. The general criticism made by him is based on the minimization of the imagination, either corrupting its object or depreciating the image as a "vulgar sensorial doubled", as well as on the "sterilization of the fecundity of the imaginary phenomenon purely and simply rejecting it or reducing it to an unskillful conceptual sketch" (Durand, 2002, p. 28), through the psychological phenomenology that separates the meaning from the significant. Moreover, he recurs to Bachelard's (1996) work to fight for the right of carrying out a systematic study of the representation without exclusion.

In the imagination domain, the image is the holder of a sense that must not be searched out of the imaginary signification. It is in the fault of the image definition as a symbol that the theories supported by Sartre (1996) and his canons let the efficacy of the imagery evaporate (Durand, 2002). The thesis in which "there is homogeneity of the significant and of the embedded meaning of an organizational dynamism in the symbol which constitutes the image" (Durand, 2002, p. 29) gains relevance through Jung (1976) who states all thought is unconsciously determined through the images, archetypes, schemes and by Piaget (1975) who defends the functional coherence of the symbolic thought and the conceptual sense - and by Bachelard (1996).

Durand (2002) dedicates a long time and great deal of analysis space to Bachelard in order to explain the option for the symbolic perspective in his work. He assumes the conception that the imaginary symbolism rests in the imagination as a dynamism organizer, and this dynamism as a factor of homogeneity in representation. The imagination starts to be recognized by both as a dynamic potency that deforms the images provided by the perception and reformulates the sensations that base the psyche. It is this coherence between the sense and the symbol that offers meaning to the metaphors and consolidates itself as a semantic of the imagery through which rationalized thought and its "semiologic cortege” (p. 31) are developed.

In Durand's description (1994), Bachelard was the pioneer of the new criticism characterized by avidity for the documents, more for the imaginary contents than for the inheritance of aesthetics ${ }^{(3)}$. It was Bachelard (1996) who constructed the literary analysis, where it is the image that illuminates the image and, thus, creates a kind of determinism transversal to history and biography. In Bachelard (1996) and in his disciples there is a liberation of the image creator of the work, of its author, of its time and represents an inversion of values that permitted to create a sociology of the imagery, completing the imperatives of imagery highlighted by the psychological and ethologic exploration, of the obscure and confused thought of the dream, of the symbol, of the myths and utopias.

From this evolution and, at the same time, knowledge fragmentation surrounding imagery, two branches of sociology of knowledge are distinguished by imagery. According to Durand (1994), one 
impregnates all the contemporary ethnology, placing the reserves of imagery (symbols, myths, rituals) at the center of the studies; the other is limited to the domains set aside by sociology.

From the original sociological trend comes the sociology of life histories, in which the investigation of the sociologist gives away to the imagery of a narrator, representing a sample of a social group (Durand, 1994). Castoriadis (2000) states that the political reasons, and those from apparently rationalized powers, loosen themselves of a passionate imagery. This thought becomes explicit in the article written by Castoriadis, in 1996, Democracy as procedure and as regime, published in the magazine Socialist Initiative.

The society-being of society are the institutions and the social imaginary significations which these institutions incarnate and cause to exist in social effectiveness. These significations are the ones that give meaning - imaginary sense, in the deep meaning of the term, i.e., spontaneous creation and unmotivated of humankind - the life, the activity, the decisions, the death of human beings, as well as the world which they create where the human beings must live and die. This polarization is not between the subject and the society [...], but between the psyche and society. The psyche must be, for better or for worse, dominated, must accept a 'reality' which is heterogeneous and strange in the beginning and, in a certain way, also until the end (Castoriadis, 1996) [Free translation].

For Castoriadis (1986), the way of being of the social dimension is the key to understanding the nature and the imagery way of working, since no social order is pure functionality. Societies organize themselves through the imaginary symbolically institutionalized significations, and these structuring symbols are impossible out of the symbolic networks that structure them. Still, society can make use of the meanings institutionalized by the symbols to instruct in the effective, although not absolute form, its members regarding cooperation and reproduction of meanings.

From the present epistemological discussion, it can be assumed that imagery, in the organizational place, flows together to the two trends here presented. In the same way that image, myths, symbols and history possess a sense produced by the imagination (Durand's thought), the mental scenarios are linked to and are not dissociated from the social-historical context where the already available symbols are given other significations, which are not their normal and canonical significations (Castoriadis's thought). Thus, the world is not universally made common to all men, but it is contextualized and not dissociated from the subjectivity and objectivity that belong to it.

\section{Analytical Potential of the Imagery Theory in the Organizational Studies}

The different analytical perspectives of imagery reveal a narrow link between imagery and organizational change and, at the same time, demonstrate possibilities of using the imagery theory in organizational studies. The link of imagery with organizational change, in Lapierre's point of view (1995), is in the leader's exercising of leadership (analytical, technical and political skills, and capacities fordirection) who possesses his/her own ghostly inner referential, and the correspondence of the visions and actions proposed by him and the wishes and needs of a group of subjects. From this relation fears, wishes, needs and feelings correlated to power are provoked, in the meaning of the term, connecting affection (cognitive element) to the knowledge and intelligence (reality elements). When exercising power, ghosts are activated or reactivated, in the cognitive dimension, like the wish to be loved and admired, fear of not being enough, fear of failure, the anxiety of competition, envy, equality and dependence.

In the organizational space, the construction and sustaining of imagery is given through the corresponding vision of the members involved, who accept serving the model proposed by the leader, as well as the collective imagery identified in the character of the leader. When making use of the psychological mechanism of projection, be it conscious or not, the leaders fascinate and break resistances in order to implant changes. In the followers memory the leader's character is stored, which begins to influence the construction of past images and to influence their life stories. Therefore, the images are a source of imagery and gain new shapes when associated with its historicity in the organizational space. 
In this manner, organizational imagery can be conceptualized as a specific imagery made up of the social construction of the institutions, symbols, socio-economic relations, influenced by the anthropological and sociological contents present in the dynamic context of a given organization. Imagery presumes an imaginative capacity for transfiguring the real, mobilizing the instituted, in addition to bringing to it meanings which are not those understood as legitimate. But imagery can be used to build an organizational ideology from a collective imagery about the organization and to build an imagery of the organization for the stakeholders, which makes it an important element in achieving legitimacy in the institutional context.

The organization creates a myth of the hero worker, responsible for the success, or the betrayer worker, who does not correspond to organizational expectations. This myth is built from metaphors presented by the managers such as: "give the company all you've got", by which they mean "get involved in organizational imagery independent of its individual representation” (Freitas, 2000).

For Aktouf (1993, p. 55), because of the narrow link with the ritual acts and moral actions, "the myth articulates itself [...] with the action and collective convictions through the process of constitution of the systems of representation, frame and the justification of behaviors". These are articulated through the images the subjects make from reality and from their positions in it. Thus, each subject possesses his imagery and his form of perceiving reality. In this way, the dialectic relationship between the imagery that formally constituted organizations develop and the imagery of each subject that forms the organizational structure can, in fact, be called organizational imagery.

The formation of organizational imagery is connected to the exercise of an implicit and unconscious power (Boonstra \& Gravenhorts, 1998), loaded with symbolisms, signs, myths and rituals. The hegemonic groups make their interpretation of reality according to the social-cultural context and build imagery around specific events that can provide a given structure and action with legitimacy. The need for organizational imagery in detriment of social imagery is justified, which does not mean that this social imagery does not contribute towards the adaptations of organizational imagery.

Several researchers have dedicated special attention to the studies of organizational change with special focus on change as a strategic aspect and, therefore, in a management perspective must be systematized under the risk of failure. This systematization presumes that organizational change is rationalized from a static reality, i.e., conceived by hegemonic groups defining means to an end to be reached through the process. However, there are limitations due to the implicit subjectivity in the construction of organizational reality because, according to Condominas (1980, as cited in Aktouf, 1993), social space is an "experienced reality", which presumes its own dynamic, connecting abstract and concrete worlds through the meanings conceived and attributed by the subjects themselves.

Therefore, the construction process of change occurs in organizational space, in a dialogic movement between economic activity, social life and symbolic life (Aktouf, 1993), through the creation and reproduction of shared meanings, those which can be destroyed and rebuilt with alternative features (Brown, 1994). In this perspective, the change occurs through the modelling of reality in the organizational space. How can this process be understood? According to Greenwood and Hinings (1996), we start from the principle that, within organizations, groups are not neutral and are not indifferent to the positions occupied by the other groups.

Thus, organizations are not monolithic structures. Different groups with different values and preferences will seek legitimacy for certain activities and events that hold their interests. The interests of the hegemonic groups can be directly or indirectly associated with the objectives and current practices and, concerning the success of the organization, such groups permanently search for the legitimacy to obtain the compliance and commitment of the other groups (Pfeffer, 1981) without which the search process becomes a hardworking exercise. The compliance reached by the hegemonic groups is also necessary in the processes of change.

The change is associated with the practices of power that take place within the organization. In this case, power is understood as the capacity for molding the reality of the organizational space and to 
preconceive all, although without making use of the explicit power according to Clegg (1987, as cited in Boonstra \& Gravenhorst, 1998). In this sense, there appears the idea that the interests of certain groups prevail over the interests of the others. This implicit power often comes from the symbolic practices that mold the members' perceptions (Greenwood \& Hinings, 1996), leading them to agendas and predefined results.

The hegemonic groups try, thus, to manage the meanings both to legitimize their demands and to delegitimize the demands of others according to Pettigrew (1977, as cited in Hardy \& Clegg, 1996). In this way, power is mobilized to influence behaviors, conceiving meanings for results, decisions and events, legitimizing or justifying them.

When molding reality, hegemonic groups build meanings around the activities that are necessary to organizational change. In these activities, the learning process of the new concepts and new activities are essential (Schein, 1994; Senge, 2001), suggesting that the change contributes to the socialization and aculturing of the subject (Brito \& Pereira, 1996; Pagés, Bonetti, Gaulejac, \& Descendre, 1987; Timothy \& Fogarty, 2001; Van Maanen, 1989) through the incorporation of new rules, values and beliefs required for the institutionalization of the different activities brought about by the change. The learning process takes place when there is forgetfulness/abandon of the habitual practices and new categories with different meanings are created instead (Weick \& Westley, 1996).

This process of learning can be constituted as a "massive use of the rituals to celebrate the commitment to the processes of change and to the leaders of change", through seminars, meetings, appointments, which help to build new shared meanings and reinforce the new order (Wood Jr., 1999).

In this construction perspective of new meanings, through the pedagogical practices mentioned above, the change in the organization occurs through the normative-re-educational strategy (Boonstra \& Gravenhorst, 1998). The idea here is that the subjects possess a certain pattern of actions supported by social-cultural norms and by the level of commitment of the subjects to these norms or to structuring practices. These practices are not always those that are of most interest to the hegemonic groups. Change in behavior occurs when the members involved in the process of change are co-opted to change their normative orientations. The modification of normative changes also involves changes in attitudes, the set of values and in shared meanings. The forms of implantation of such a strategy can vary substantially due to the context of change.

The process of change that establishes the new order demands strategies for its maintenance. The technology, the architecture or the forms of management emerge as administrative functions of control and policing at a distance, albeit without compromising the domain (Ball \& Wilson, 2000; Clegg, 1992; Foucault, 1987). These functions of control gain support in the development of new technologies which allow the monitoring of the work being carried out and the accomplishment of certain specifications, through the use of machinery, demonstrating the non neutrality of the forms of management (Cappelle \& Brito, 2002) applied to the new instituted organizational order.

However, the present perspective has limitations. First, the practices developed by the hegemonic groups are not necessarily conscious. The institutional context in which the subjects are imbricated creates difficulties for the hegemonic groups when manipulating symbols and values that they share among themselves. Secondly, the present perspective considers the existence of a high level of conformity among the members who occupy less privileged positions. In this way, it is clear that the dispositions of the members in the organizations tend to be constant due to the capacity of the hegemonic groups to turn domination into something legitimate and without confrontation.

Why would the groups accept to be dominated? Here, the important notion of organizational outflanking emerges, according to Van Maanen (1986, as cited in Hardy \& Clegg, 1996), which reveals why the dominated often consent to their own domination. The members consent, on the one hand, because they do not know enough to resist and, on the other hand, because they know the futility of such an action (Hardy \& Clegg, 1996). In the second alternative there lies the idea of direct non resistance by the acceptance of the survival rules which structure the organizational space, i.e., 
members recognize the ongoing game, know their rules and subject themselves to the maintenance of their individual conditions within the space.

Therefore, it could be said that organizations build those imageries that receive efforts to be instituted, legitimizing change and keeping the new order. There is no singularity of imageries, but, at the same time, the organization exists due to instituted imageries and, because of that, in some way acts as dominator by expressing the interests of those who dominate.

\section{FinAL CONSIDERATIONS}

The effort to bring the knowledge of sociology, anthropology, analytical psychology and social psychology into the discussion of organizational imagery presents some challenges. Due to its attempt to approach these knowledge areas with administration, there will always be a search concerning the function of imagery or its importance in the change processes. Nevertheless, the organizational change is directly connected with the construction of the reality through the actions of the hegemonic groups. Comprehending this process is nothing more than learning the organizational imagery. This is the reason that sustains, at one time, the option for the interpreting paradigm of analysis to the detriment of the functionalist tradition in the organizational studies, and the imagery study in the organizational space, using the methodological guidelines of Minayo (2001) and Spink (2000), especially for involving analysis of speech and language studies.

The theoretical reflection induces the thought of organizational imagery accessed by the subject's objectivities (real), through language (expressiveness), where the images attributed to the real with all its subjectivity (feelings, emotions, sensations) will emerge, which will not always be visible to the researcher. The identification of the object image as representation can guide the researcher only to the representations of the referred object without, however, having access to what the image hides, that is, the affection allowed by the symbol (ceremonies, rituals, slogans, metaphors). In the symbol image all the phenomena inherent in the subject's historicity are found, which makes the access process to the imagery something concerning the dynamism of the investigation space.

Therfore, imagery is constructed by the dynamism of the relations between the people inserted in the inter relations between real-image-symbol (reality) in addition to keeping the networks of meanings and mobilizing what was instituted. The final construction is a report without the limits imposed by the frame, expressed by language and materialized by the attributed meaning whose content belongs to the specific organization and only to that organization.

Once the construction process of the organizational imagery has been understood, in an atmosphere of change, in a dialogic movement between different worlds (economic, social, symbolic), it is easier to reflect on the relations of conflict and consensus which are inserted in the context of change. However, it is necessary to improve research in order to describe the methodological procedures of access to imagery, a proposal which is not contemplated in this article and, thus, to test the analytical potential of imagery in organizational studies.

\section{NOTES}

\footnotetext{
${ }^{1}$ Lapierre, in 1984, organized a symposium with the objective of comprehending the leadership phenomenon, establishing a direct connection with the subjective reality of those who execute it (exterior practices), according to their narration and how they can be observed in relation to their inner reality. The methodology adopted sought differentiation of the traditional university colloquies and it was structured on "case studies", i.e.,, reports of research which had elements of a case history integrated with interpretations, analyses and explanations of the researcher, according to several theories or grids of analysis.
} 


\begin{abstract}
2 The master's speech does not work in the relation subject-subject; for the master, the other is an object like any other element of the organization. Its relations of dialogue are limited to constructing myths and ceremonies of alienation of the subjects-objects, as its real objective is to make the organization work. In this context, the strength of imagery works in favor of the alienation of the staff that alienate themselves bythe wish of others; the opportunity to speak and to express their wishes is not given to them. From the construction of relations based on the boss's speech emerges what Freud denominated "speculated relations", where the workers are stuck in the boss, leader and/or hero's image. It is as if they have looked into a mirror and identified the boss in that image. They construct a desire to "follow the boss", which is also an alienating relation. It is relevant to point out that the imagery context, in most relations, is not conscious or voluntary. This hampers much more the breaking of these barriers, because only the subject or the subjects of analysis can break this speech. This conception of imagery allows us to analyze this register as being part of the context of what is real, including bringing in elements that often, in research situations, cannot be pre-judged. Abstaining from what is real is essential to comprehending singular imageries.

3 "New literary and artistic criticism" was a sociological trend which considered the image illuminated by the image and began to valorize the documents, specially the texts and masterpieces in a significant way (Durand, 1994).
\end{abstract}

\title{
REFERENCES
}

Aktouf, O. (1993). O simbolismo e a cultura de empresa: dos abusos conceituais às lições empíricas. In J. F. Chanlat (Ed.). O indivíduo nas organizações (pp. 39-79). São Paulo: Atlas.

Altman, E. C. (1995). O conceito de imaginação: uma história inacabada (O. L. S. Torres, Trans.). In L. Lapierre (Cood.) \& O.L.S. Torres (Org. Bras.), Imagem e liderança: na sociedade, no governo, nas empresas e na mídia (Vol. 1, pp. 77-91). São Paulo: Atlas. (Original work published 1992).

Avens, R. (1993) Imaginação é realidade (Coleção Psicologia Analítica). Petrópolis: Vozes.

Bachelard, G. (1996). A poética do espaço (A. P. Danesi, Trans.). São Paulo: Martins Fontes. (Original work published 1957).

Baczko, B. (1985). A imaginação social. (Enciclopédia Einaudi. Anthropos-Homem, Vol. 5). Lisboa, Portugal: Imprensa Nacional/Casa da Moeda.

Ball, K., \& Wilson, D. C. (2000). Power, control and computer-based performance monitoring: repertoires, resistance and subjectivities. Organization Studies, 21(3), 539-565.

Barreto. C. R. (1993). Sobre a racionalidade humana: conceitos, dimensões e tendências. Anais do Encontro Nacional dos Programas de Pós-Graduação em Administração, Salvador, BA, Brasil, 17.

Berger, P., \& Luckmann, T. (2002). A construção social da realidade: tratado de sociologia do conhecimento (F. S. Fernandes, Trans.). (22th. ed.). Petrópolis: Vozes. (Original work published 1966).

Boonstra, J. J., \& Gravenhorst, K. M. B. (1998). Power dynamics e organizational change: a comparison of perspectives. European Journal of Work and Organizational Psychology, 7(2), 97-120.

Bourdieu, P. (2001). O poder simbólico (F. Tomaz, Trans.). (4th. ed.). Rio de Janeiro: Bertrand Brasil. (Original work published 1989).

Brito, M. J., \& Pereira, V. G. (1996). Socialização organizacional: iniciação na cultura militar. Revista Brasileira de Administração Pública, 30(4), 138-165. 
Brown, A. D. (1994). Politics, symbolic action and myth making in pursuit of legitimacy. Organization Studies, 15(6), 861-878.

Cappelle, M. C. A., \& Brito, M. J. (2002). A dinâmica do poder no espaço organizacional: uma análise do caráter disciplinas das práticas de gestão da força de trabalho. Anais do Encontro Nacional dos Programas de Pós-Graduação em Administração, Salvador, BA, Brasil, 26.

Castoriadis, C. (1986). El campo de lo social histórico. Hemeroteca Virtual, Asociación Nacional de Universidades e Instituciones de Educación Superior. Retrieved from http://www.hemerodigital.unam.mx/ANUIES/itam/estudio/estudio04/sec_3.html

Castoriadis, C. (1996, Febrero). La democracia como procedimiento y como regimen. Iniciativa Socialista, (38).

Castoriadis, C. (1999). Para si e subjetividade. In A. Pena-Veja \& E. P. Almeida (Eds.). O pensar complexo: Edgar Morin e a crise da modernidade (3th ed., pp. 35-46). Rio de Janeiro: Garamond.

Castoriadis, C. (2000). A instituição imaginária da sociedade (G. Reynaud, Trans.). (5th. ed., Vol. 52, Coleção Rumos da Cultura Moderna). Rio de Janeiro: Paz e Terra. (Original work published 1975).

Clegg, S. (1992). Tecnologia, instrumentalidade e poder nas organizações. Revista de Administração de Empresas, 32(5), 69-95.

Durand, G. (1994). L'Imaginaire: essai sur les sciences et la philosophie de l'image. Paris: Hatier.

Durand, G. (2002). As estruturas antropológicas do imaginário: introdução à arquetipologia geral (H. Godinho, Trans). (3th.ed.). São Paulo: Martins Fontes. (Original work published 1969).

Enriquez, E. (1974). Imaginário social, recalcamento e repressão nas organizações. Rio de Janeiro: Tempo Brasileiro.

Foucault, M. (1987). Vigiar e punir: a história da violência nas prisões. Petrópolis: Vozes. (Original work published 1975).

Freitas, M. E. (2000). Contexto social e imaginário organizacional moderno. Revista de Administração de Empresas, 40(2), 6-15.

Greenwood, R., \& Hinings, C. R. (1996). Understanding radical organizational change: bringing together the old and the new institucionalism. The Academy of Management Review, 21(4), 1022-1046.

Hardy, C., \& Clegg, S. R. (1996). Some dare call it power. In S. R. Clegg, C. Hardy, \& W. R. Nord (Eds.). Handbook of organization studies. London: Sage.

Jung, C. G. (1976). Tipos psicológicos (A. Cabral, Trans). (3th ed.). Rio de Janeiro: Zahar (Original work published 1921).

Lacan, J. (1983) Seminário I: os escritos técnicos de Freud. Rio de Janeiro: Zahar.

Lacan, J. (1985). O seminário: livro 20, mais, ainda. (2a ed.). Rio de Janeiro: Zahar.

Lapierre, L. (Coord.) \& O. L. S. Torres (Org. Bras.) (1995). Imagem e liderança: na sociedade, no governo, nas empresas e na mídia (O. L. S. Torres, Trans.). (Vol. 1). São Paulo: Atlas. (Original work published 1992). 
Larçon, J.-P., \& Reitter, R. (1979). Structure de pouvoir et identité de l'entreprise. Paris: Nathan.

Minayo, M. C. S. (Ed.). (2001). Pesquisa social: teoria, método e criatividade. (18th ed.). Petrópolis: Vozes.

Pagés, M., Bonetti, M., Gaulejac, V., \& Descendre, D. (1987). O poder nas organizações. São Paulo: Atlas.

Pfeffer, J. (1981). Management as symbolic actions: the creation and maintenance of organizational paradigms. Research in Organizational Behavior, 3, 1-52.

Piaget, J. (1975). A formação do símbolo na criança: imitação, jogo e sonho imagem e representação. (2nd. ed.). Rio de Janeiro: Zahar.

Sartre, J-P. (1964). A imaginação. São Paulo: Difusão Européia do Livro.

Sartre, J-P. (1996). O imaginário: psicologia fenomenológica da imaginação. São Paulo: Ática.

Schein, E. H. (1994). On dialogue, culture, and organizational learning. Organizational Dynamics, 22, 40-51.

Senge, P. (2001). A nova tarefa do líder: formar organizações de aprendizado. In H. Mintzberg \& J. B. Quinn (Eds.). O processo da estratégia. (3rd. ed., pp. 213-221). Porto Alegre: Bookman.

Serva, M. (1997). Abordagem substantiva e ação comunicativa: uma complementaridade proveitosa para a teoria das organizações. Revista de Administração Pública, 31(2), 108-134.

Spink, M. J. P. (2000). (Org.). Práticas discursivas e produção de sentidos no cotidiano: aproximações teóricas e metodológicas. (2nd. ed.). São Paulo: Cortez.

Timothy J., \& Fogarty, M. W. D. (2001). Organizational socialization as instrument and symbol: an extended institutional theory perspective. Human Resource Development Quartely, 12(3), 247266.

Trindade, L., \& Laplantine, F. (1997). O que é imaginário (Coleção Primeiros Passos, n. 309). São Paulo: Brasiliense.

Van Maanen, J. (1989). Processando as pessoas: estratégias de socialização organizacional. In M. T. L. Fleury, \& R. M. Fischer (Coords). Cultura e poder nas organizações. (pp. 45-62). São Paulo: Atlas.

Weick, K. E., \& Westley, F. (1996). Organizational Learning: affirming an oxymoron. In S. R. Clegg, C. Hardy, \& W. R. Nord (Eds.). Handbook of organization studies. London: Sage Publications.

Wood Jr, T. (1999). Organizações de simbolismo intensivo. Anais do Encontro Nacional dos Programas de Pós-Graduação em Administração, Foz do Iguaçu, PR, Brasil, 23. 